\title{
Effect of petrography and diagenesis on the sandstone reservoir quality: a case study of the Middle Miocene Kareem Formation in the North Geisum oil field, Gulf of Suez, Egypt
}

\author{
Mohamed F. Abu-Hashish ${ }^{1} \cdot$ Hamdy M. Afify ${ }^{2}$
}

Received: 20 September 2021 / Accepted: 9 February 2022 / Published online: 4 March 2022

(c) The Author(s) 2022

\begin{abstract}
Kareem Formation is one of the most important hydrocarbon reservoirs in the Gulf of Suez. It contributes significantly to the total Egyptian oil production; therefore, the current work is to emphasise the influence of siliclastic facies types and their diagenetic processes on the reservoir quality of the Kareem Formation. A comprehensive log and core analyses were used to determine both the petrophysical and petrographical characteristics. Three classic facies have been identified: two sandstone facies with reservoir potential and one shale facies. Facies I is coarse-grained sandstone with high-angle cross-bedding, distributary/braided channel deposits on the active part of a mid-submarine fan lobe and is represented by beds of (Shagar Member). Facies II is fine-grained sandy beds represented by low-angle crudely, cross-bedded sandstone encountered in the Rahmi Member. Facies III is mainly shale and recorded in the Rahmi clastic zone. Petrographically, the quartz arenite microfacies are dominant in the Shagar sand zone and show the highest potential zones in the Kareem Formation. On the other hand, quartz lithic arenite and calcareous lithic arenite constitute the major microfacies in the Rahmi clastic zone and show the lowest reservoir quality. The main diagenetic processes that enhance the sandstone reservoir intervals of the Kareem Formation are the microfracturing of mineral grains and the dissolution of both feldspar and carbonate cement. In contrast, the amount of cementing materials, particularly authigenic carbonate and clay cements, led to diminishing of the reservoir quality of the studied Kareem Formation.
\end{abstract}

Keywords Reservoir quality $\cdot$ Petrophysical properties $\cdot$ Kareem Formation $\cdot$ Geisum field $\cdot$ Gulf of Suez $\cdot$ Egypt

\section{Introduction}

The impact of the sedimentary facies and the diagenetic processes on the reservoir quality of the siliclastic reservoir rocks have been discussed by many authors, including Abouessa and Morad (2009), Ajdukiewicz and Lander (2010), Bjørlykke (2014), Khalifa and Morad (2015), Olivarius et al. (2015), Nabawy and Géraud (2016), Nabawy and El Sharawy (2018), Nabawy et al. (2020), Abuhagaza et al. (2021), Kassem et al. (2021) and Zhang

Responsible Editor: Santanu Banerjee

Mohamed F. Abu-Hashish

mfarouk64@gmail.com

1 Geology Department, Faculty of Science, Menoufia University, Shebin El-Kom, Egypt

2 PetroGulf Misr Petroleum Company, Cairo, Egypt et al. (2021). The Gulf of Suez lies between Sinai and the northern section of Egypt's Eastern Desert. It has a width of $50-105 \mathrm{~km}$, a length of around $330 \mathrm{~km}$ and an area of roughly $250,000 \mathrm{~km}^{2}$. It is a NW-SE trending rift feature initiated most probably during the Late Oligocene (Khalil and McClay 2001). Its significance stems from the wide range of rocks, from Precambrian to modern, that include good to outstanding hydrocarbon source rocks and reservoirs; it is an excellent example of hydrocarbon accumulation linked with rifting (London, 1995). The North Geisum oil field is located in the northern section of the main Geisum concession, between latitudes $27^{\circ} 40^{\prime} 9.3^{\prime \prime}$ and $27^{\circ} 41^{\prime} 2.157^{\prime \prime} \mathrm{N}$ and longitudes $33^{\circ} 39^{\prime} 0.59^{\prime \prime}$ and $33^{\circ}$ $39^{\prime} 47.9^{\prime \prime}$ E. (Fig. 1). It lies southeast of Zeit Bay in the offshore southern portion of the Gulf of Suez, roughly $40 \mathrm{~km}$ north of Hurghada City, and covers an area of around 40 $\mathrm{km}^{2}$. Because of the existence of pinnacle and barrier reefs that encircle the island, the region is characterised by rapid variations in water depth ranging from 0 to $60 \mathrm{~m}$. The 


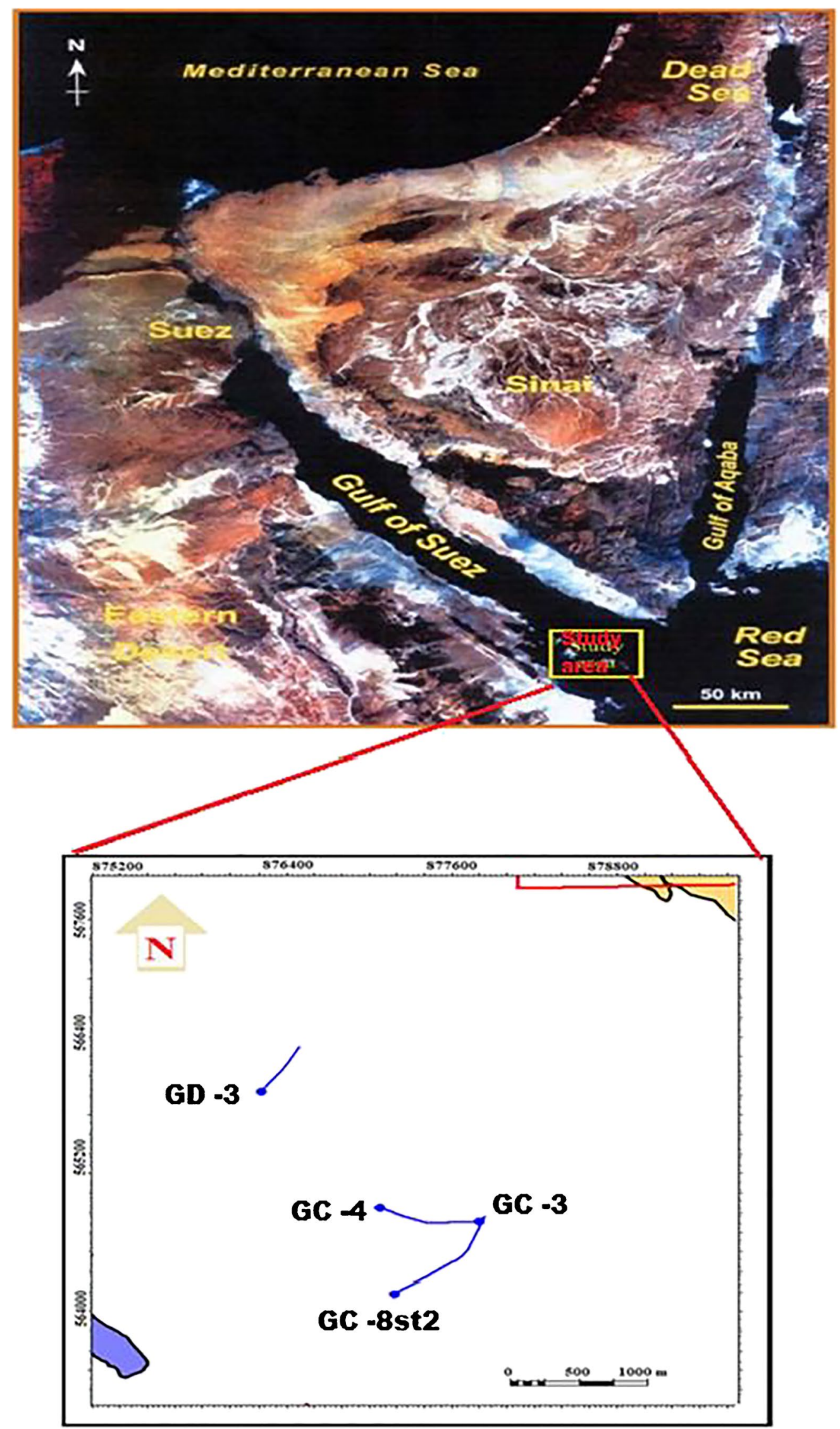


4Fig. 1 Location map of the study area

main goal of this study is to shed more light on the impact of microfacies and post-depositional processes on the reservoir quality of the Kareem Formation's clastic intervals in the Geisum oil field.

\section{Geologic settings}

The Red Sea and Gulf of Suez form a rift system with an extensional regime that is more or less perpendicular to their border faults, whereas the Gulf of Aqaba is a leaky transform basin with a strike slip regime; the rift basin stretches northwest from the Red Sea and began during the Oligocene-Miocene epoch (Moustafa and Khalil 2020). The Gulf of Suez has developed in a series of distinct evolutionary stages from the Palaeozoic to the Holocene and is characterised by tectonic extensional episodes producing tension block faulting (horst and graben) and block subsidence (Fig. 2). The first-stage, Palaeozoic terrestrial clastics were deposited over a Precambrian crystalline basement with minor tectonic movements (Bosworth and McClay 2001). The hiatus caused by these movements is evident in the thinning or absence of sedimentation in many parts of the Gulf of Suez. The second stage occurred during the Permian-Triassic to Jurassic and is characterised by local subsidence and minor transgression, leading to deposition of fluvio-marine red shales and sandstones. The third stage dates from the Early Cretaceous and involved rifting of the continental crust, under tension, to produce a system of grabens via block faulting. In the fourth stage, which extended from the middle Cretaceous to the Miocene, normal faulting continued, and the graben system gradually subsided to form a deep basin. Marine sandstone and shallow marine limestone, including reefal limestone, were deposited on structural highs, whereas shale and Globigerina marl accumulated in the low areas. The last strata of this stage were thick salt deposits. In the fifth and final stage, during the Pliocene-Holocene period, the inner fracture system deepened, the basin fill was raised near the rift borders due to continuing block faulting and the non-marine wedge-top strata (mostly sandstone) infiltrated the basin (Alsharhan 2003).

The original structure of the Gulf of Suez comprises northwest tilted fault block sand horsts because of the early rifting between African and Arabian plates in the Late Mesozoic and the Early Tertiary times when fault blocks by NE-SW cross faults existed, which developed and tilted with plunging towards the northwest (Afifi et al. 2013, 2016). The average structure dip of the penetrated pre-Miocene and Miocene sedimentary units ranges from $35^{\circ}$ to $45^{\circ}$ in the Nubia-Matulla formations that gradually decreases upward to about $8^{\circ}$ in the Kareem Formation. Generally, these sedimentary units are thinning up dip towards the crestal area of the tilted blocks, either due to the non-deposition over the highs or because of the pre-Miocene unconformity (Patton et al. 1994).

The stratigraphic section of the Gulf of Suez comprises rock units ranging in age from Pre-Cambrian to Holocene. Three lithostratigraphic sequences are recognised through the Gulf of Suez area: (a) The pre-rift stratigraphic sequence is composed of strata ranging in age from the Precambrian to the Late Eocene (Omran and El Sharawy 2014), from sand, shale and carbonate facies that were laid down under terrestrial and marine platform environments. This period of sedimentation was affected by major unconformities representing non-deposition or erosion at different geologic times (Alsharhan 2003). (b) The syn-rift sediments that were put down during the rifting (Alsharhan and Salah 1994) are composed of the Miocene formations (Abu Zenima, Nukhul, Rudeis and Kareem formations), and the formation is divided into two members (Shagar Member and Rahmi Member). (c) Sediments from the Middle Miocene to the recent represent the post-rift lithostratigraphic units.

\section{Kareem Formation}

The Kareem Formation is a syn-rift rock unit (Fig. 3) that is predominantly shale with frequent intervals of sandstones. The interbedded sands provide excellent reservoirs with porosities ranging from 11 to 24\% (Abd El-Naby et al. 2010). The palaeo-depositional environments are difficult to interpret because of a lack of faunal content (Wescott et al. 1996). The Kareem Formation is subdivided into two members: Shagar Member at the top and Rahmi Member at the bottom. The Shagar Member consists mainly of shale and limestone with sandstone streaks. The shale is light grey, dark grey and greenish grey in colour; soft to moderately compact; and highly calcareous grading to marl, sandy and silty in parts. The sandstone is mainly white, and occasionally pink; fine to medium grained; occasionally coarse grained; sub-angular to subrounded; moderately sorted; with calcareous cement; and cherty in parts and pyritic in other parts (Hammad 2009). The Shagar Member is divided into Shagar cap and Shagar sand beds. On the other hand, the Rahmi Member can be subdivided into Rahmi anhydrite bed, followed by Rahmi clastic bed that is composed of shale, siltstone, limestone and streaks of sand called intra-Rahmi sand, and at its lower part there is thick sandstone called basal Rahmi sand bed (Salah and Alsharhan 1997). A chart of stratigraphic correlations has been constructed to show the lateral variations in formation thickness, lithology content, unconformity and strata equivalent values, and accordingly, the wells have to correlate and interpret the major sequence from the well data (Fig. 4). The Shagar Member is subdivided into two beds (Shagar cap and Shagar sand beds). Shagar sand bed reaches its maximum thickness (89 ft.) at GC-8ST2 well 
Fig. 2 Tectonic map of the Gulf of Suez Region map (after Bosworth et al. 2005)

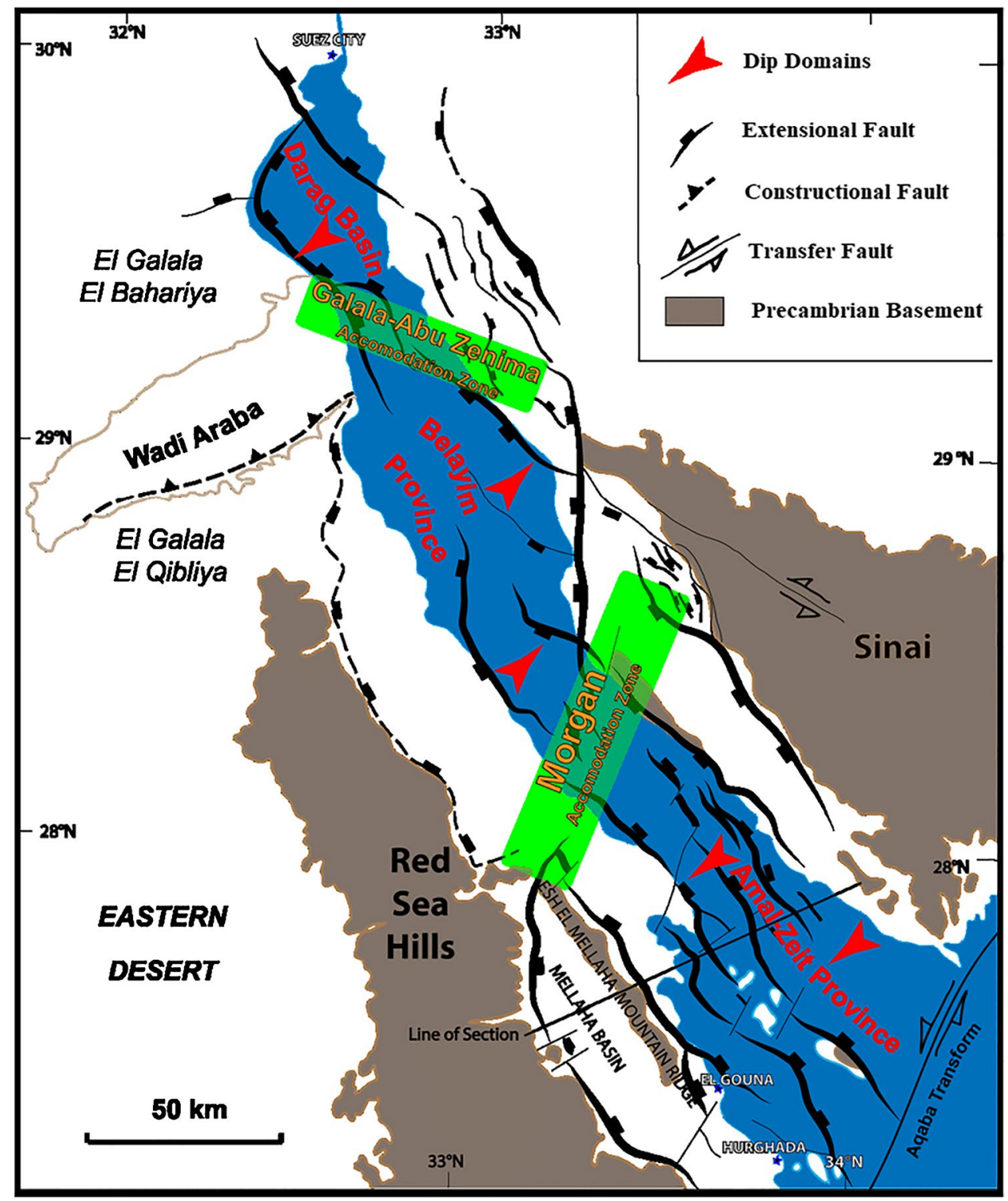

and minimum around GD-3 well (37 ft.) which is composed mainly of sandstone. The Rahmi Member is divided into Rahmi anhydrite, Rahmi clastics and Rahmi sand beds. The lithology varies from shale with sandstone and limestone streaks (GC-4-GD-3 and GC-3) to limestone and sandstone at the GC-8ST2 well.

\section{Materials and methods}

The current work aims to use the integration of both core and well $\log$ data to do a comprehensive petrophysical characterisation of the Kareem Formation in North Geisum oil field, based on four selected wells (GC-3, GD-3, GC-4 and GC8st2). The log data include gamma, resistivity, neutron, density and sonic logs. Accurate reservoir properties and mapping of the reservoir heterogeneity are carried out. Petrographic investigation was performed using thin section and scanning electron microscopy (SEM). Three samples were subjected to X-ray diffraction (XRD) analysis using Philips X-ray diffraction equipment (model PW/1710), with $\mathrm{Ni}$ filter and $\mathrm{Cu}$ radiation $(\lambda=1.542 \AA)$ at $40 \mathrm{kV}$ and 30 MA. Fractions finer than $4 \varnothing$ in each sample were collectively analysed for the clay mineral identification beside the other associated minerals.

\section{Results and discussion}

\section{Well log analysis}

The well log data of four wells in North Geisum field have been processed and interpreted in order to determine the 
Fig. 3 Generalised stratigraphic column of the Gulf of Suez Rift and lithostratigraphic composite $\log$ for the study wells (Darwish and El-Araby 1993)

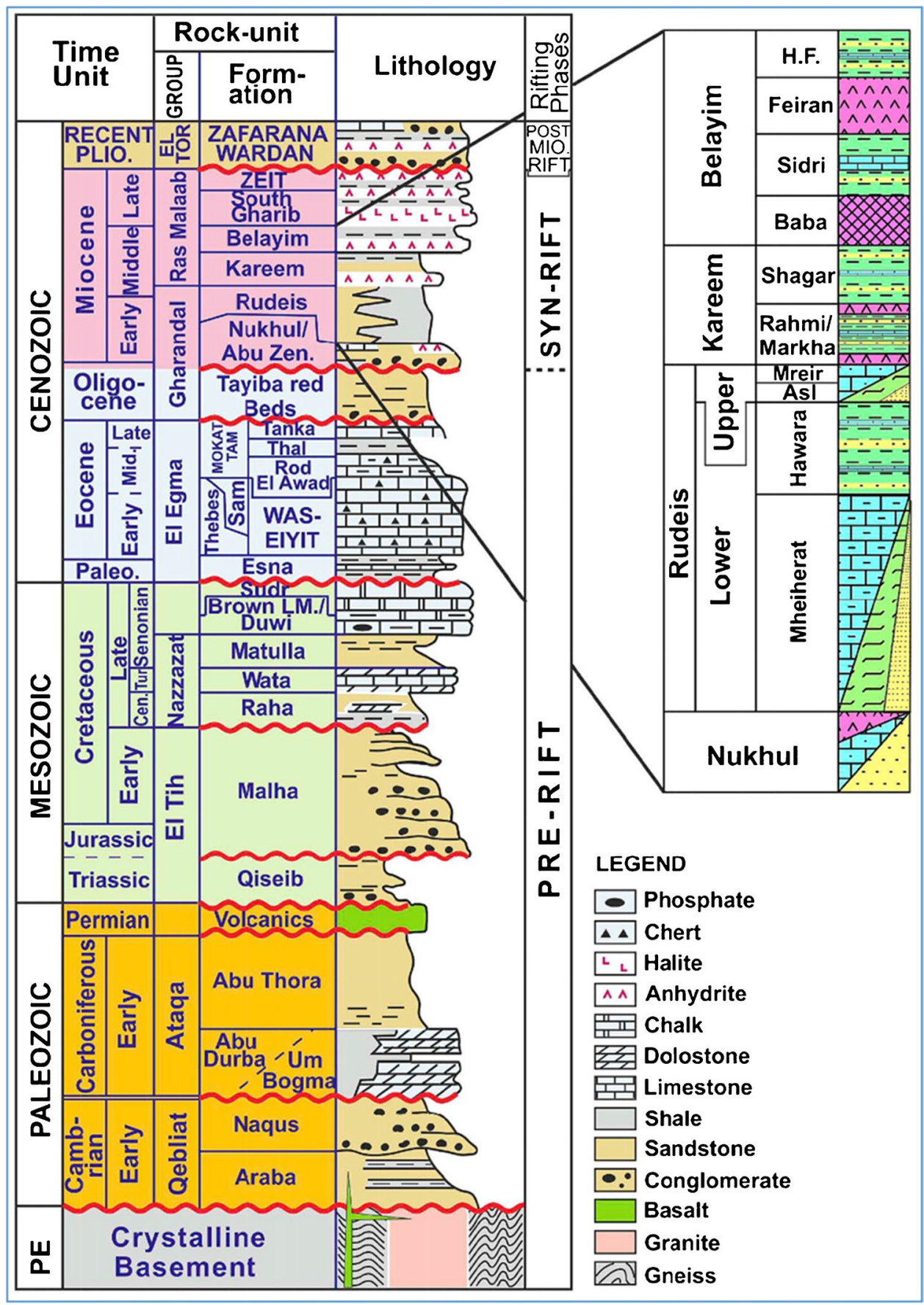

reservoir characterisations of the Kareem Formation and its reservoir beds. The log set includes gamma, resistivity, neutron, density and sonic logs. Lithology identification and estimation of the petrophysical parameters (shale volume, porosity and fluid saturation) were performed, and the results are tabulated in Table 1. Some cross plotting relationships have been constructed to help identification of the distribution behaviour of the well logging-deduced parameters, particularly the porosity. These cross plots (computer-processed interpretation (CPI), neutron density and sonic density) will facilitate the qualitative interpretation of some log responses, e.g. deducing the mineral constitute and lithology in the studied rock units.

\section{CPI of GC-3 well}

All available data for the interval 4774 to $5428 \mathrm{ft}$. (Fig. 5) show that the Kareem Formation in the study area can be subdivided into Shagar and Rahmi members from top to bottom, respectively. In addition, the Shagar Member can 
Fig. 4 Stratigraphic correlation chart for wells in the NW-SE direction

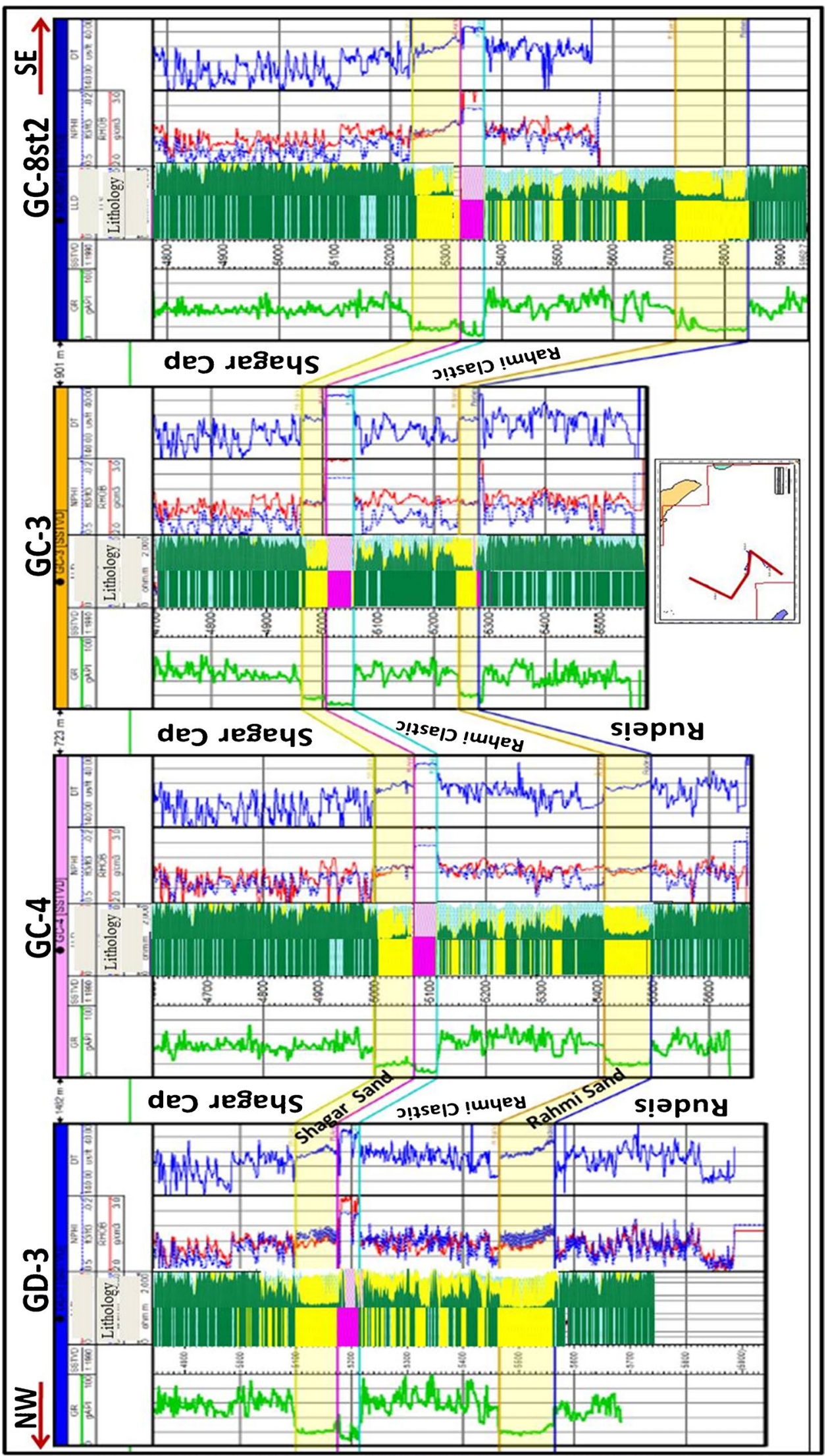


Table 1 The average values of the $\log$ analysis parameters of the Kareem Formation in the GC-3 well

\begin{tabular}{llllllllll}
\hline Zone Name & Top & Bottom & Av Vcl & Av Sw & Av PhiE & Av PhiT & Gross & Net & N/G \\
\hline Shager cap & 4777.5 & 5093.5 & 0.222 & 1 & 0.195 & 0.254 & 316 & 10 & 0.032 \\
Shager sand & 5093.5 & 5138.5 & 0.033 & 0.117 & 0.187 & 0.195 & 45 & 42.5 & 0.944 \\
Rahmi anhydrite & 5138.5 & 5190 & - & - & - & - & 51.5 & 0 & 0 \\
Rahmi clastic & 5190 & 5384 & 0.138 & 0.472 & 0.415 & 0.187 & 194 & 18 & 0.093 \\
Rahmi sand & 5384 & 5428 & 0.043 & 0.32 & 0.182 & 0.194 & 44 & 36 & 0.818 \\
All zones & 100 & 5720 & 0.436 & 1.909 & 0.709 & 0.83 & 650.5 & 106.5 & 1.887 \\
\hline
\end{tabular}

Depth units: $\mathrm{ft}$

$V c l$ volume of shale, PhiE effective porosity, PhiT total porosity be subdivided into Shagar cap and Shagar sand beds. The Shagar cap bed is dominated by mainly shale with streaks of limestone, and its gross thickness is $316 \mathrm{ft}$. The shale content is high which reaches its maximum value at middle while decreases towards upper and lower parts. The average shale volume of this formation is about $22 \%$, and the average water saturation is $100 \%$, which is considered as a cap rock of Shagar sand reservoir. Shagar cap bed followed by highly calcareous sand body increases downward, which is called Shagar sand bed, and its gross thickness is $45 \mathrm{ft}$. The average shale volume of this bed is about $3 \%$, the average total porosity is about $19.5 \%$, the effective porosity is $18 \%$, the water saturation is $11.7 \%$ and the hydrocarbon saturation is $88.3 \%$. It is considered as a good reservoir, especially in the upper part, which have high porosity and low water saturation. The Rahmi Member is subdivided into Rahmi anhydrite, Rahmi clastic and Rahmi sand beds where the Rahmi anhydrite bed is consisting of anhydrite attaining a thickness of $51.5 \mathrm{ft}$. and is downward followed by the Rahmi clastic bed. Rahmi clastic bed is composed of shale, limestone and streak of sand called intra-Rahmi sand which reached $18 \mathrm{ft}$. in the GC-3 well. The gross thickness of Rahmi clastic bed is $194 \mathrm{ft}$. The average shale volume of this bed is about $14 \%$, the average total porosity is about $18.7 \%$, the effective porosity is $14.6 \%$, the water saturation is $46 \%$ and the hydrocarbon saturation is $54 \%$. In the lower part of the Kareem Formation, there is thick sandstone called Rahmi sand bed. Its gross thickness is $44 \mathrm{ft}$. The average shale volume of this bed is about $5 \%$, the average total porosity is about $18 \%$, the effective porosity is $18 \%$, the water saturation is $31 \%$ and the hydrocarbon saturation is $69 \%$.

NEU/DEN cross plot for the studied wells was constructed where the Shagar sand bed is composed mainly of sand with a minor amount of highly calcareous sand increase downward, the Rahmi clastic bed is made up mainly of shale with limestone and sandstone streaks and the Rahmi sand bed is mainly composed of sandstone streaks (Fig. 6). The sonic/density cross plot in the available wells in the study area demonstrates that Shagar sand, Rahmi clastics and Rahmi sand beds are lying under the same range of density readings between 2.3 and $2.6 \mathrm{~g} / \mathrm{cm}^{3}$, while the sonic readings range between 50 and $70 \mu \mathrm{s} / \mathrm{ft}$. This cross plot indicates the absence of the evaporate minerals in sandstone, limestone and shale (Fig. 7).

\section{Sedimentary facies}

Based on the cutting description and core photo, three distinct sedimentological facies were recognised:

- Facies I: Represented by beds of coarse-grained sandstone (Shagar Member), it shows a high-angle cross-bedded, distributary/braided channel deposit on the active part of a mid-submarine fan lobe (Fig. 8A). Thin pebbly interbeds concentrated along reactivation surfaces represent channel lags at the base of individual channel sand bodies. Vertical accretion of these sand bodies produces a multi-system reservoir. In the Shagar Member, this facies attains about $28^{\prime} 5^{\prime \prime}$.

- Facies II: The finer sandy beds that are represented by low-angle crudely, cross-bedded fine-grained sandstone encountered in the Rahmi Member are interpreted as a moderate- to high-energy deposit on the distal margin of a mid-submarine fan lobe (smooth mid fan) (Fig. 8B).

- Facies III: It is mainly shale, with a high content of microplankton, leading to the assumption that this shale was deposited from suspension in a distal mid-fan lobe to outer fan setting. This facies is found in the Rahmi Member (Rahmi clastics). It does not have any reservoir potential as it is composed mainly of shale.

\section{Environmental interpretation}

The coarse-grained sandstone facies (facies I) represents high-energy sand deposition in a distributary channel setting of a supra-fan lobe (mid-submarine fan complex) by sediment gravity flows (grain flow) (Armitage et al. 2010). The fining upward internal trend, moderate- to high-angle cross-bedding (trough cross-bedding) and scoured cross-bed set and co-set boundaries indicate continuous and rapid deposition of channel sands amalgamated one above the other. 
Scale : $1: 500$

GC-3 Well

$08: 6-3($ : $)$

10/8/20001015

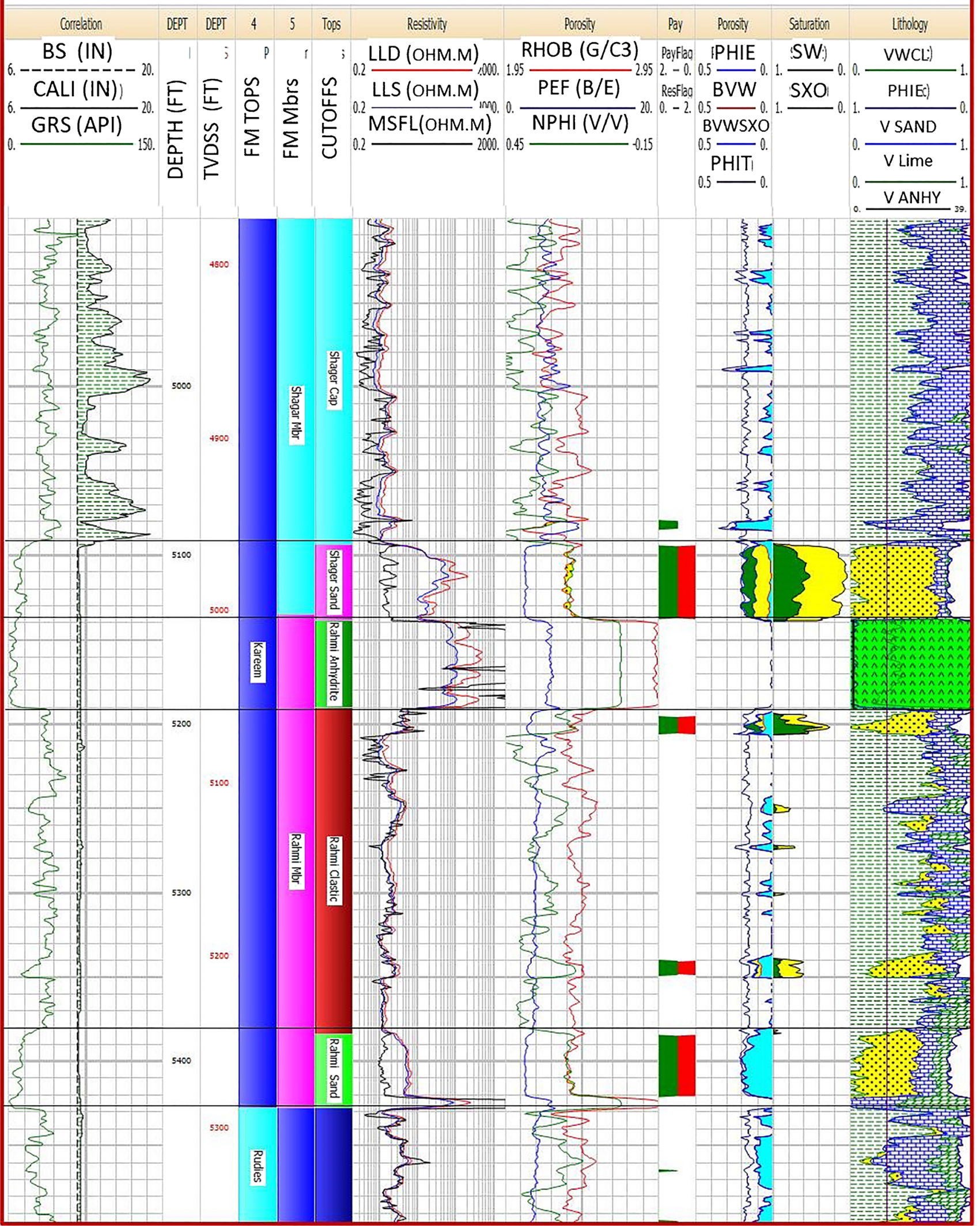


४Fig. 5 Computer-processed interpretation (CPI), $\{$ GC-3 well $\}$

Thin pebbly interbeds associated with scoured reactivation surfaces represent channel lags at the base of individual channel sand bodies. Facies II is interpreted as a moderate- to high-energy deposit on the distal margin of a mid-submarine fan lobe (smooth mid-fan). The cross-bedded and well-sorted sandstone beds indicate deposition by relatively strong currents that flowed across the surface of the fan lobe during turbidity events. In the deep-sea fan models of Walker (1978) and Normark (1978), these types of beds would be classified as outer fan or distal mid-fan deposits. The claystone facies (facies III) is interpreted as a deep marine suspension fallout deposit occurring in an outer fan setting away from the active submarine fan lobes. The presence of abundant marine fossils (microplankton and planktonic microfauna) in association with high fissility and minor bioturbation indicates a quiet and deep-water environment of deposition.

\section{Reservoir potential}

The porosity/permeability cross plot data (Fig. 9) displays three distinct subpopulations: the first population with high porosity and permeability represents intervals with low or no calcareous cement (facies I), and it attains moderate to high reservoir potential with an average vertical and horizontal permeability of $255 \mathrm{mD}$ and $825.0 \mathrm{mD}$, respectively, and an average helium porosity of about $18.1 \%$. The second population with moderate porosity and permeability represents intervals with abundant carbonate cement (facies II), and the low permeability and porosity is mainly due to the
Fig. 6 Neutron-density cross plot of reservoir beds for the GC-3 well

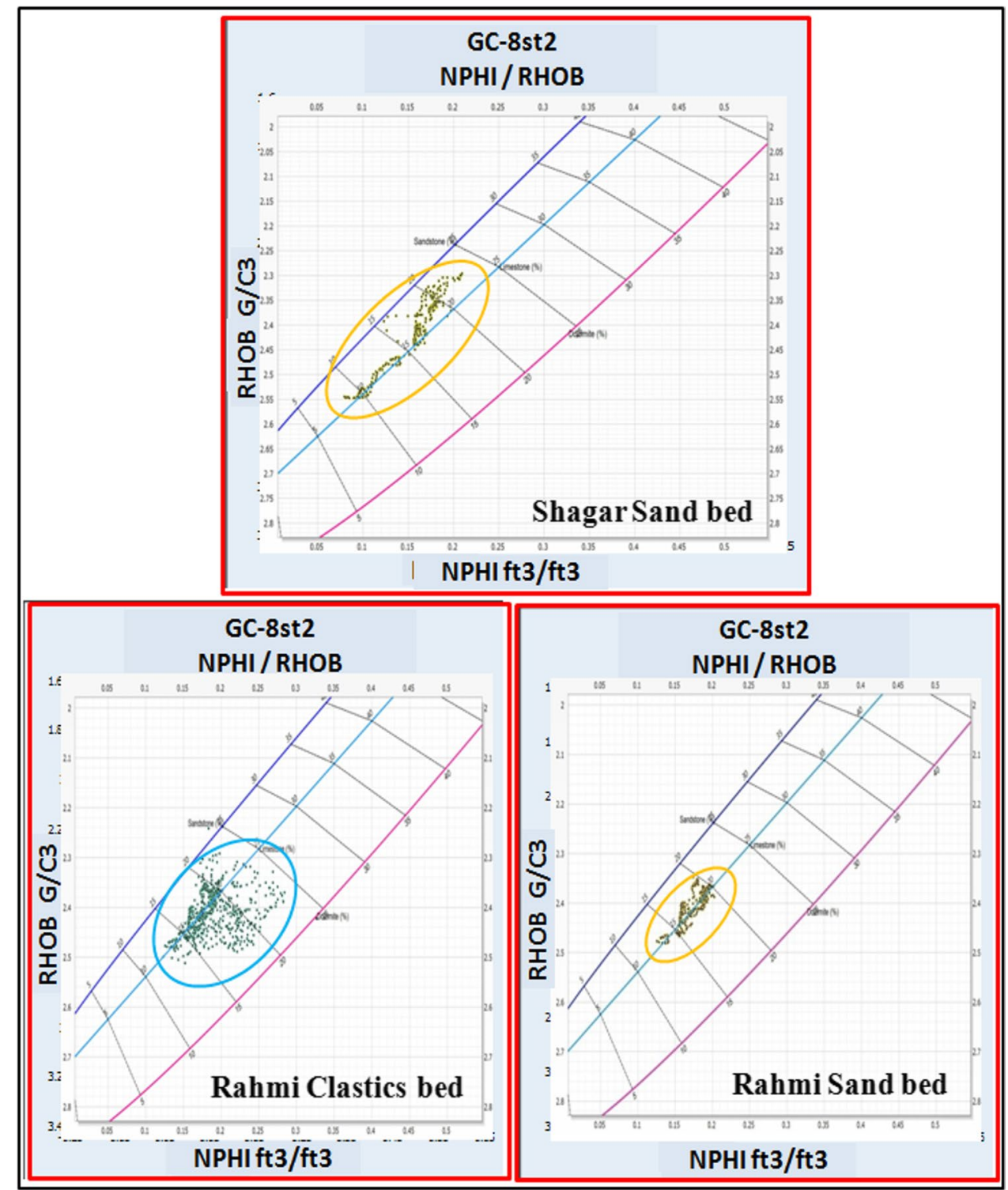


Fig. 7 Sonic-density cross plot of reservoir beds, $\{$ GD-3 well $\}$

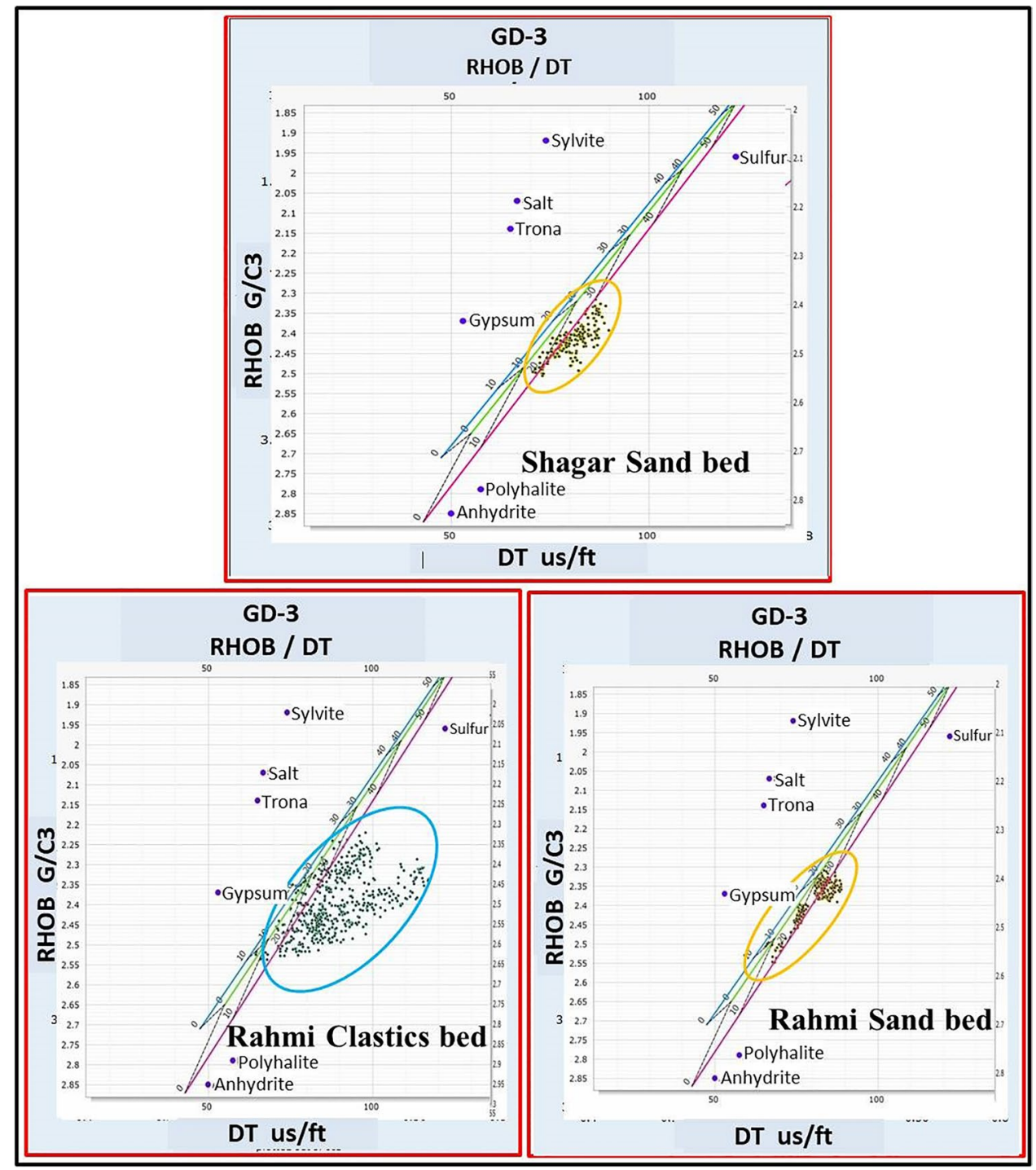

argillaceous nature of the sediment. Calcareous cementation also played a role in reducing porosity and permeability. This facies has low reservoir potential with an average vertical and horizontal permeability of $5.9 \mathrm{mD}$ and $19.8 \mathrm{mD}$, respectively, and helium porosity of $13.2 \%$. Facies III is composed of shale and has no reservoir potential, but it acts as a seal between potential reservoir intervals (Table 2).

\section{Petrography}

Samples representing the Shagar sand zone show a sublithic arenite microfacies with medium- to coarse-grained, moderately sorted sandstone, dominantly composed of quartz grains partly possessing quartz overgrowths (Fig. 10A). Porosity is dominantly secondary interparticle and partly occluded by kaolinite, pyrite, ferroan dolomite and detrital clay. Rock fragments are minor and include carbonate clasts (Fig. 10B). This facies displays moderate to high reservoir potential with generally good porosity and permeability, with $22 \%$ point-counted porosity, $2285 \mathrm{mD}$ horizontal permeability, $24 \%$ helium porosity and $436 \mathrm{mD}$ vertical permeability. Rahmi Member microfacies samples are represented in two microfacies; petrographic examination of the samples representing the Rahmi Member revealed that two microfacies were recoded: lithic arenite and calcareous lithic arenite. The lithic arenite microfacies is composed of medium-grained, poor to moderately sorted sandstone with abundant pore filling calcite cement, feldspar and detrital clay (dark brown) (Fig. 10C, D), while the calcareous lithic arenite microfacies are composed of quartz and lithics as major framework grains with subordinate calcite dolomite cements and detrital clays (Fig. 10E, F). Facies II is more immature, compared to facies I, and it is more calcareous and feldspathic. It shows poor reservoir quality due to finer grain sizes and higher carbonate cement. 
Fig. 8 A Core photo of facies I coarse-grained high-angle cross-bedded sandstone. B Core photo of facies II fine-grained low-angle cross-bedded sandstone

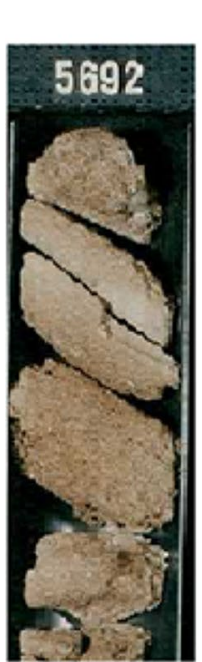

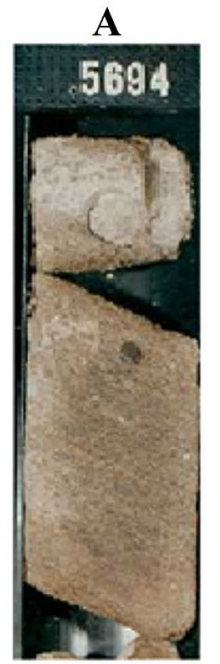

Facies I
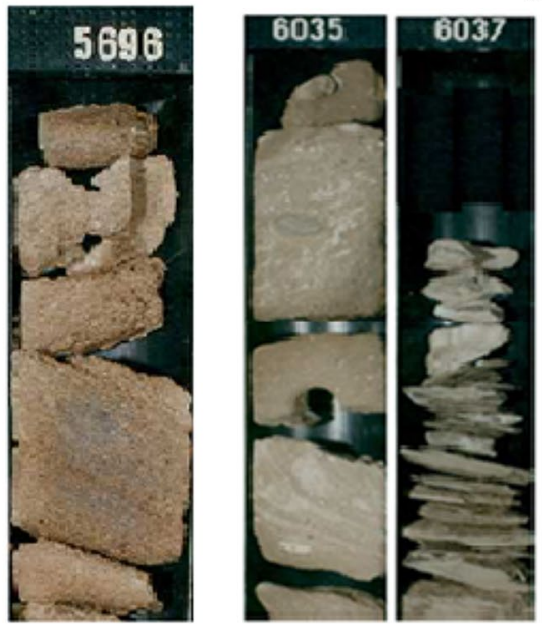

Facies II
B
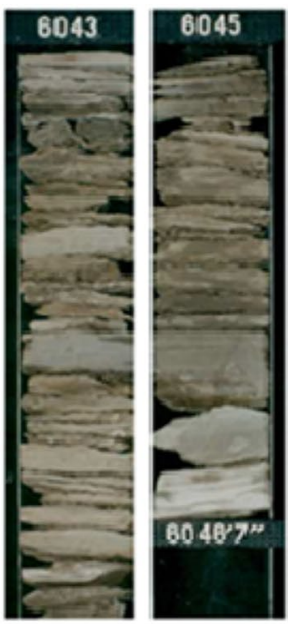

\section{Mineralogy}

Untrained monocrystalline quartz with undulose and nearstraight extinction is an important framework grain type, while the polycrystalline quartz is common in all the samples and is ranging from 1.5 to $14.5 \%$ by volume. These grains show predominantly non-equigranular mosaics with sutured grain contacts (Fig. 10A). Lithic grains are the second major framework component in the examined samples; it ranges from 1.5 to $16 \%$ by volume. Major lithic components in facies I include fossiliferous limestone, clay and carbonate cements (Fig. 10B). Feldspars form a relatively minor component of facies I, ranging from 1 to $3 \%$ by volume. Potassium feldspars are common and include microcline, orthoclase and perthite. Potassium feldspars are dominantly altered and partly leached. Plagioclase feldspars are less abundance (trace quantities to $1 \%$ by volume) and slightly altered. In facies II, potassium feldspars comprise $17 \%$ of the rock volume (Fig. 10C). Glauconite is found in most of the analysed samples and ranges from 0.5 to $3 \%$ by volume. Glauconite grains are usually well rounded to very well rounded and green to brown in colour. The matrix of detrital clay is found in all the analysed samples. It ranges from 4 to $11 \%$ by volume. The clay matrix occurs both as a pore filling phase and as rims around detrital grains. SEM analysis indicates that the primary detrital clays are occasionally recrystallised and overgrown by authigenic chlorite or replaced by the late diagenetic carbonate cement (Fig. 10C, D).

\section{Diagenetic features}

\section{Dissolution}

The most important observed diagenetic processes of the Kareem Formation that enhance greatly the porosity are the microfracturing due to the mechanical compaction (Fig. 10D) and the dissolution of feldspar and carbonates. The dissolution of feldspar grains in sandstone reservoirs has a major impact on the reservoir's primary petrophysical properties and quality (Xiao et al. 2018); this phenomenon is often documented in facies II and greatly enhances the secondary porosity values (Fig. 10C, D). The dissolution of carbonate (both calcite and dolomite) cements is recorded in both facies I and facies II, which enhance greatly the porosity and the permeability of the Kareem sands (Fig. 10A).

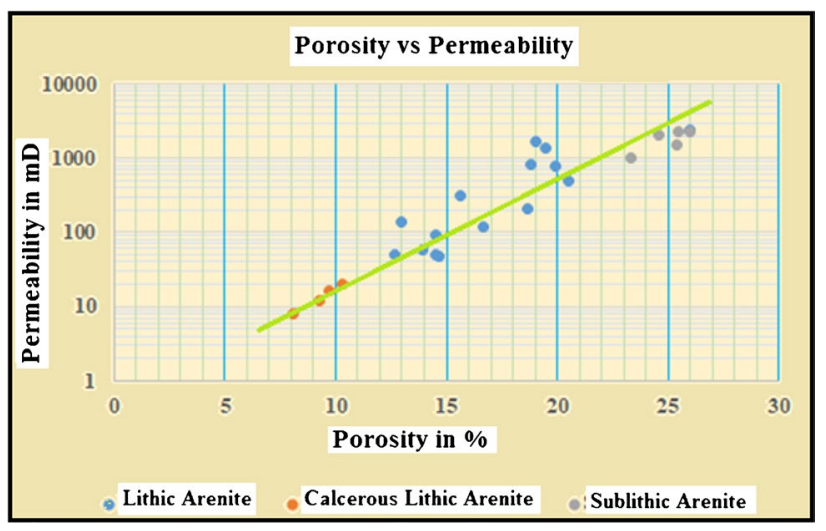

Fig. 9 Porosity-permeability relationship of clastic intervals in the Kareem Formation in the GC-4 well 
Table 2 Conventional core analysis of the Kareem Formation in the GC-4 well

\begin{tabular}{|c|c|c|c|c|c|}
\hline $\begin{array}{l}\text { Sample } \\
\text { number }\end{array}$ & Porosity in $\%$ & $\begin{array}{l}\text { Vertical perme- } \\
\text { ability in } \mathrm{mD}\end{array}$ & $\begin{array}{l}\text { Horizontal per- } \\
\text { meability in } \mathrm{mD}\end{array}$ & Rock unit & Microfacies \\
\hline 1 & 26 & 1900 & 2225 & Shagar sand & Sublithic arenite \\
\hline 2 & 23.3 & 2000 & 1000 & Rahmi sand & Lithic arenite \\
\hline 3 & 25.5 & 2410 & 2257 & & \\
\hline 4 & 24.6 & 1998 & 2051 & & \\
\hline 5 & 25.4 & 1854 & 1502 & & \\
\hline 6 & 14.5 & 88 & 91 & & \\
\hline 7 & 26 & 1100 & 2437 & & \\
\hline 8 & 18.8 & 75 & 833 & & \\
\hline 9 & 16.7 & 51 & 120 & & \\
\hline 10 & 19.5 & 980 & 1353 & & \\
\hline 11 & 13.9 & 20 & 58 & & \\
\hline 12 & 15.6 & 215 & 305 & & \\
\hline 13 & 13 & 58 & 135 & & \\
\hline 14 & 20.5 & 91 & 491 & & \\
\hline 15 & 14.5 & 31 & 51 & & \\
\hline 16 & 19 & 48 & 1700 & & \\
\hline 17 & 12.7 & 11 & 49 & & \\
\hline 18 & 14.7 & 9 & 48 & & \\
\hline 19 & 18.7 & 192 & 206 & & \\
\hline 20 & 19.9 & 16 & 800 & & \\
\hline 21 & 9.7 & 3 & 16 & Rahmi clastics & Calcareous lithic arenite \\
\hline 22 & 9.3 & 6 & 12 & & \\
\hline 23 & 8.1 & 7 & 8 & & \\
\hline 24 & 10.3 & 3 & 20 & & \\
\hline
\end{tabular}

\section{Authigenic minerals}

Calcite occurs as a cement and grain-replacive phase in facies I. It ranges from 3 to $17 \%$ by volume, and it dominantly occurs as sparry cement partly or totally occluding pores and also replacing detrital grains. SEM and thin section examinations show that the calcite cement shows corroded crystal margins following late-stage leaching by aggressive pore fluids (Fig. 11A). Ferroan calcite is the dominant pore occluding cement in facies II and ranges from 6 to $21 \%$ by volume. It is recorded as a trace quantity in facies I. Ferroan calcite significantly occludes all visible intergranular porosity, which results in an apparent floating grain contact fabric. Ferroan dolomite serves both as a rim cement around detrital grains and as an intergranular cement. Ferroan dolomite is recognised in all facies and ranges from 1.5 to $13 \%$ by volume. Two stages of dolomite precipitation are recorded. The first stage mainly occurs as very finely crystalline rhombohedral crystals around detrital grains. The second stage comprises euhedral aggregates of ferroan dolomite in secondary pores (Fig. 11A, B).

Kaolinite occurs in the form of vermicular aggregates and booklets in the secondary pores (Fig. 11C). Smectite is a clay mineral that was only recorded by XRD analysis
(Fig. 12), and it is probably a component of the detrital clay fraction. Illite is only recorded in trace amounts in thin section analysis. The occurrences of illite in the XRD traces are thought to be associated with feldspar degradation and claystone clasts. Chlorite is present in XRD traces but in little amounts. SEM examination reveals that chlorite, which occurs as micron-sized platelets, overgrows detrital clays and occurs in secondary pores associated with the authigenic kaolinite. The matrix of clay minerals greatly reduces the reservoir permeability especially illite and chlorite that modify the structure of pore radiuses and minimise the fluid flow (Fig. 11C, D). Significant occurrences of early diagenetic pyrite are closely associated with the finer-grained sandstone facies (facies II). It reaches up to $6 \%$ by volume. In facies I, pyrite ranges from 0.5 to $1 \%$ by volume. Two stages of pyrite precipitation were recorded in the analysed samples. The first stage replaces detrital clays. Cubic pyrite crystals growing in both primary and secondary pore spaces characterise the second stage. The variation in cement types in Kareem clastic intervals, as well as the overlap of different diagenetic processes, has a significant impact on reservoir heterogeneity, particularly in facies II in Rami sand and Rahmi clastic zones, causing a relative gap in vertical and horizontal permeability values in some intervals (Fig. 13). The diagenetic 
Fig. 10 Photomicrographs showing A the silica cement overgrowths and the pore spaces in the sublithic arenite microfacies, $\mathbf{B}$ the preservation of the original calcite cements in the sublithic arenite microfacies, $\mathbf{C}$ the dissolution of both feldspar grain and the carbonate cement in the lithic arenite microfacies, D the intergranular porosity (in blue colour) as well as fracture porosity in quartz grains in the lithic arenite microfacies, $\mathbf{E}$ the complete reduction of pore spaces due to the carbonate cementing in the calcareous lithic arenite microfacies and F the non-porous, poikilotopic calcite cement in the calcareous lithic arenite microfacies
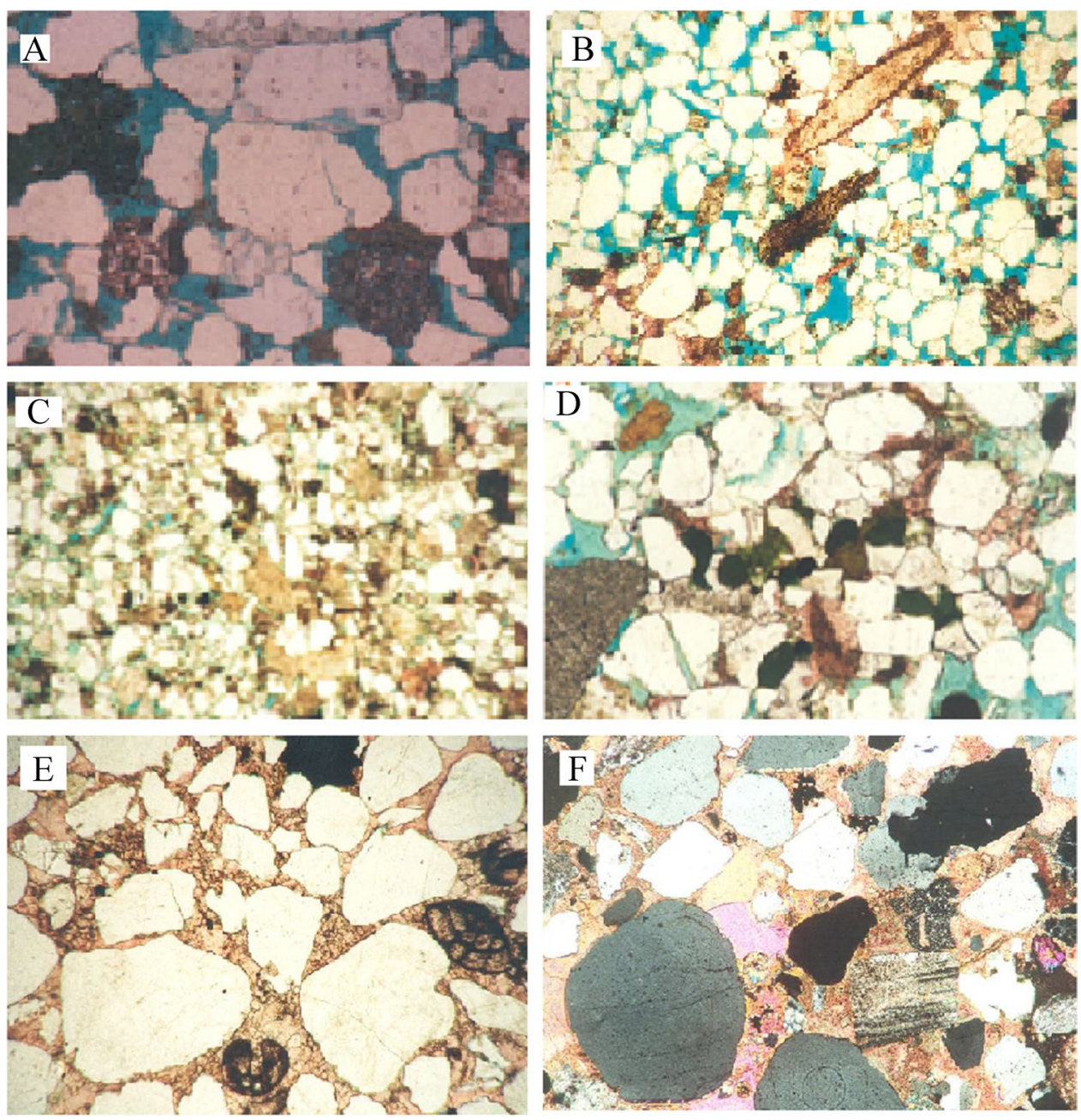
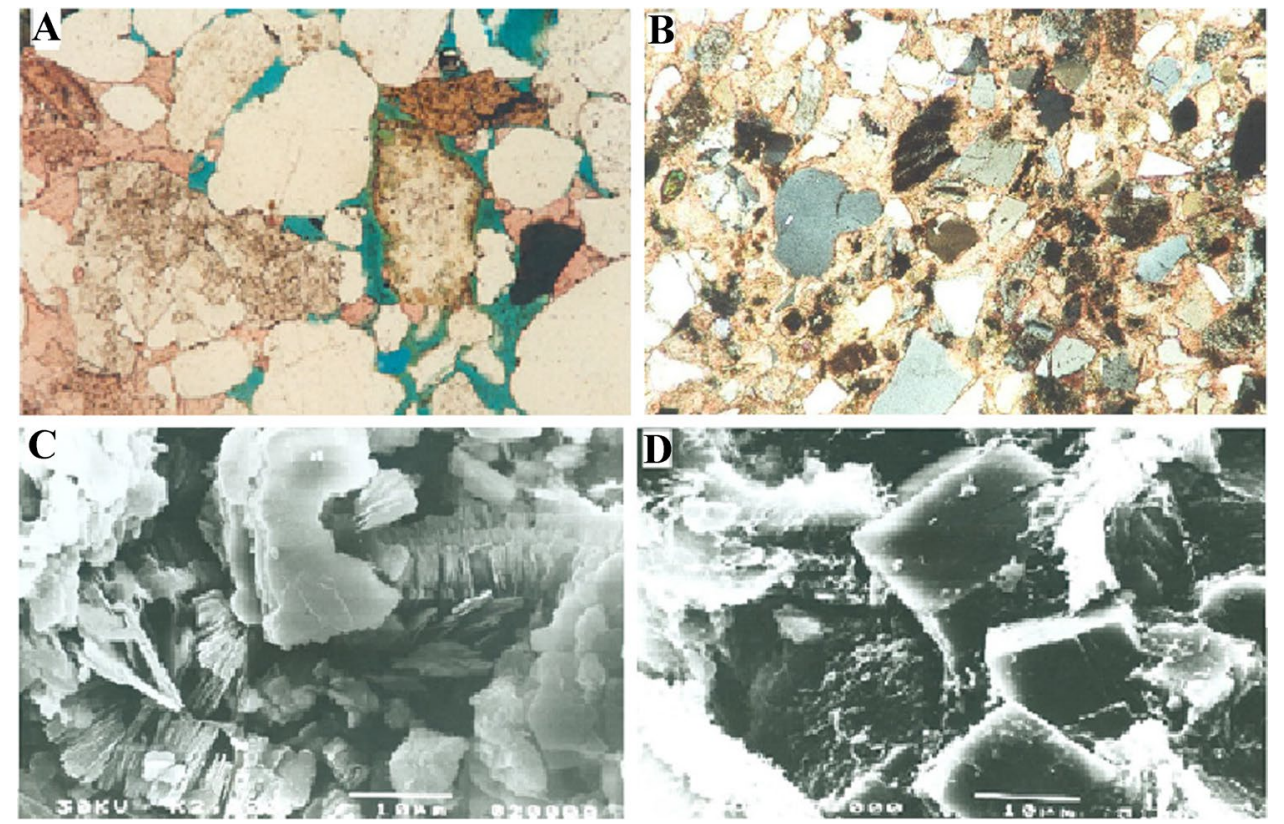

Fig. 11 Photomicrographs showing A the partial dissolution of the dolomite cement enhancing the intergranular pore spaces (in blue colour), B the dolomite cement completely filling the pore spaces (note the glauconite pellets in green colour), C SEM micrograph showing the well-developed kaolinite crystals filling the pore spaces and D SEM micrograph showing the dolomite rhombs in association with pore lining and grain coating authigenic clay (mixed layered smectite/ illite clay) 
Fig. 12 X-ray diffraction chart of the bulk sample of Rahmi Member, \{GD-3 well $\}$
Fig. 13 Relationship between vertical and horizontal permeability of the clastic intervals in the Kareem Formation, \{GC-4 well \}
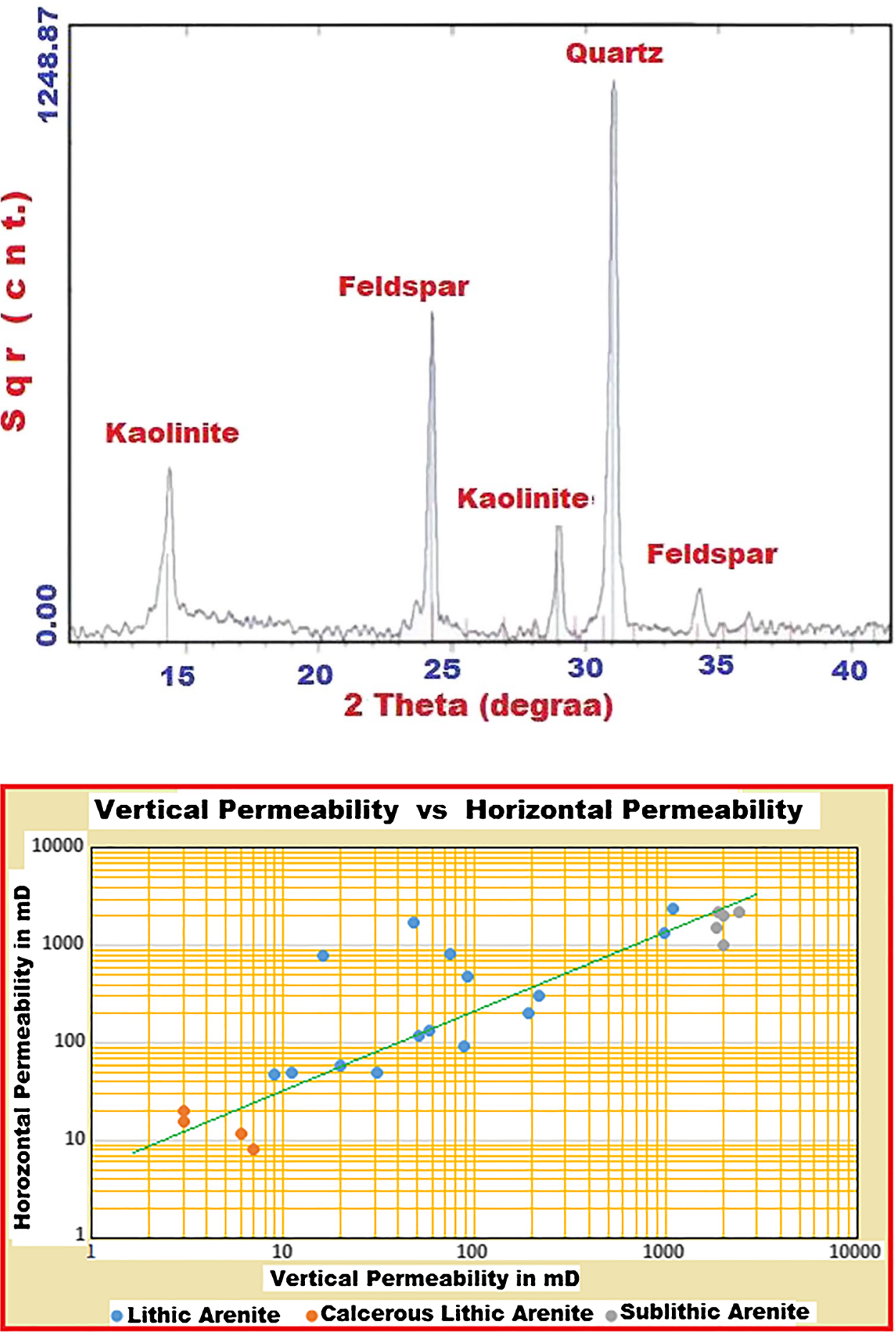

history of the studied sandstone samples of the Kareem Formation can be summarised as follows: The near-surface diagenesis includes (a) detrital clay rim cement and (b) mechanical compaction and closer grain packing, while the shallow burial diagenesis includes (a) quartz overgrowths and (b) continued burial and compaction. The deep burial diagenesis includes (a) chlorite and kaolinite precipitation, (b) late-stage ferroan dolomite precipitation and (c) pyrite precipitation. It is well observed that the most important diagenetic processes that occlude the porosity in descending order are calcite precipitation, Ferroan calcite precipitation, Ferroan dolomite precipitation, clay authigenesis, quartz overgrowths, compaction and associated processes. On the other hand, the dissolution of carbonates and feldspar is the most important diagenetic process, which enhances porosity. 


\section{Conclusions}

The comprehensive well log evaluation of the Kareem Formation indicates that three distinct reservoir zones are recorded with different levels of petrophysical properties and hydrocarbon potentiality. Description of cuttings and core of the clastic intervals in the Kareem Formation reflects three sedimentary facies (facies I, facies II and facies III) in Shagar sand, Rahmi sand and Rahmi clastics. Facies I is made up of sands that were deposited in high-energy sand deposition in a distributary channel of a supra-fan lobe (mid-submarine fan complex). Facies I is represented by sublithic arenite microfacies with medium- to coarse-grained texture. This facies has good reservoir quality with about $25 \%$ porosity and 1.8 darcy permeability. Facies II and III represent the Rahmi Member. Facies II has a moderate- to high-energy deposit on the distal margin of a mid-submarine fan lobe and is made up of lithic arenite and calcareous lithic arenite microfacies. Facies III is mainly shale with no reservoir potential. Petrographically, two microfacies are present: the lithic arenite and calcareous lithic arenite with fine- to medium-grained texture. Lithic arenite shows moderate reservoir quality while calcareous lithic arenite suggests poor reservoir quality. In terms of diagenesis, obvious diagenetic factors enhance greatly the reservoir quality; the dissolution of both carbonate cements and feldspar grains and the fracturing of quartz grains due to compaction add many values to both porosity and permeability. In addition, low level of dissolution of carbonate cement partially or completely reduces both the porosity and permeability. The reservoir permeability is much reduced because of the presence of clay matrix especially illite and chlorite.

Acknowledgements The authors wish to express their thanks and gratitude to the Egyptian General Petroleum Corporation (EGPC) and the PetroGulf Misr Petroleum Company for the permission and release of the data for this research.

Funding Open access funding provided by The Science, Technology \& Innovation Funding Authority (STDF) in cooperation with The Egyptian Knowledge Bank (EKB).

\section{Declarations}

Conflict of interest The authors declare that they have no competing interests.

Open Access This article is licensed under a Creative Commons Attribution 4.0 International License, which permits use, sharing, adaptation, distribution and reproduction in any medium or format, as long as you give appropriate credit to the original author(s) and the source, provide a link to the Creative Commons licence, and indicate if changes were made. The images or other third party material in this article are included in the article's Creative Commons licence, unless indicated otherwise in a credit line to the material. If material is not included in the article's Creative Commons licence and your intended use is not permitted by statutory regulation or exceeds the permitted use, you will need to obtain permission directly from the copyright holder. To view a copy of this licence, visit http://creativecommons.org/licenses/by/4.0/.

\section{References}

Abd El-Naby A, Abd El-Aal M, Kuss J, Boukharay M (2010) Stratigraphy interpretation of structurally controlled deposition: Middle Miocene Kareem Formation, southwestern Gulf of Suez, Egypt. Geo Arabia 15(3):129-150

Abouessa A, Morad S (2009) An integrated study of diagenesis and depositional facies in tidal sandstones: Hawaz Formation (Middle Ordovician), Murzuq Basin, Libya. J Petrol Geol 32(1):39-65

Abuhagaza AA, Kassab MA, Wanas HA, Teama MA (2021) Reservoir quality and rock type zonation for the Sidri and Feiran members of the Belayim Formation, in Belayim Land Oil Field, Gulf of Suez, Egypt. J Afr Earth Sci 181:104242

Afifi A, Moustafa AR, Helmy H (2013) Structural evolution of the southern Gulf of Suez Rift: implications for hydrocarbon exploration in a mature basin. Egypt Geophys Soc 10:12-31

Afifi AS, Moustafa AR, Helmy HM (2016) Fault block rotation and footwall erosion in the southern Suez Rift: implications for hydrocarbon exploration. J Mar Pet Geol 76:377-396

Ajdukiewicz JM, Lander RH (2010) Sandstone reservoir quality prediction. The state of the art. Am Assoc Petrol Geol Bull 94(8): 1083-1091

Alsharhan AS (2003) Petroleum geology and potential hydrocarbon plays in the Gulf of Suez Rift Basin, Egypt. AAPG Bull 87:143-180

Alsharhan AS, Salah MG (1994) Geology and hydrocarbon habitat in a rift setting: southern Gulf of Suez, Egypt. Bull Can Petrol Geol 42(3):312-331

Armitage PJ, Worden RH, Faulkner DR, Aplin AC, Butcher AR, Iliffe J (2010) Diagenetic and sedimentary controls on porosity in Lower Carboniferous fine-grained lithologies, Krechba field, Algeria: a petrological study of a cap-rock to a carbon capture site. Mar Pet Geol 27(7):1395-1410

Bjørlykke K (2014) Relationships between depositional environments, burial history and rock properties. Some principal aspects of diagenetic process in sedimentary basins. Sediment Geol 301:1-14

Bosworth W, McClay K (2001) Structural and stratigraphic evolution of the Gulf of Suez Rift, Egypt: a synthesis. In: Ziegler PA, Cavazza W, Robertson AHF, Crasquin-Soleau S (eds) PeriTethys Memoir 6: Peri-Tethyan rift/wrench basins and passive margins. Museum National d'Histoirenaturelle de Paris, Memoirs, 186:567-606

Bosworth W, Huchon P, McClay K (2005) The Red Sea and Gulf of Aden basins. In: Catuneanu O, Guiraud R, Eriksson P, Thomas B, Shone R, Key R (eds) Phanerozoic evolution of Africa. J Afr Earth Sci 43:334-378

Darwish M, El-Araby AM (1993) Petrography and diagenetic aspects of some siliciclastic hydrocarbon reservoirs in relation to the rifting of the Gulf of Suez, Egypt. Geological Society of Egypt, Special Publication, 1155-187

Hammad AE (2009) Geologic control of geopressure pattern in Belayim oil field-Gulf of Suez, Egypt. In: Geology Department. Cairo University. M.Sc., Cairo

Kassem AA, Hussein WS, Radwan AE, Anani N, Abioui M, Jain S, Shehata AA (2021) Petrographic and diagenetic study of siliciclastic Jurassic sediments from the northeastern margin of Africa: implication for reservoir quality. J Petrol Sci Eng 200:108340 
Khalifa MA, Morad S (2015) Impact of depositional facies on the distribution of diagenetic alterations in the Devonian shoreface sandstone reservoirs, southern Ghadamis Basin, Libya. Sed Geol 329:62-80

Khalil SM, McClay KR (2001) Extensional fault-related folding, northwestern Red Sea, Egypt. J Struct Geol 24(2002):734-762

McClay KR, Nicols GJ, Khalil SM, Darwish M, Bosworth W (1998) Extensional tectonics and sedimentation, eastern Gulf of Suez, Egypt. In: Purser BH, Bosence DWJ (eds) Sedimentation and tectonics in rift basins, Red Sea-Gulf of Aden. Chapman and Hall, London, pp 223-238

Moustafa AR, Khalil S M (2020) Structural setting and tectonic evolution of the Gulf of Suez, NW Red Sea and Gulf of Aqaba Rift systems. p. 306 after Z. Hamimi et al. (eds) The Geology of Egypt, Regional Geology Reviews, Springer Nature Switzerland AG

Nabawy BS, Géraud Y (2016) Impacts of pore- and petro-fabrics, mineral composition and diagenetic history on the bulk thermal conductivity of sandstones. J Afr Earth Sc 115:48-62

Nabawy BS, Elgendy NTH, Gazia MT (2020) Mineralogic and diagenetic controls on reservoir quality of Paleozoic sandstones, Gebel El-Zeit, North Eastern Desert, Egypt. Nat Resour Res 29:1215-1238

Nabawy BS, El Sharawy MS (2018) Reservoir assessment and quality discrimination of Kareem Formation using integrated petrophysical data, southern Gulf of Suez, Egypt. Mar Petrol Geol 93:230-246 search, $1-24$

Normark WR (1978) Fan valleys, channels and depositional lobs on modem submarine fan: characters for recognition of sandy turbidite environment. AAPG Bull 62:912-931

Olivarius M, Weibel R, Hjuler ML, Kristensen L, Mathiesen A, Nielsen LH, Kjøller C (2015) Diagenetic effects on porosity-permeability relationships in red beds of the Lower Triassic Bunter Sandstone Formation in the North German Basin. Sed Geol 321:139-153

Omran MA, El Sharawy MS (2014) Tectonic evolution of the southern Gulf of Suez, Egypt: a comparison between depocenter and near peripheral basins. Arab J Geosci 7(1):87-107

Patton TL, Moustafa AR, Nelson RA, Abdine SA (1994) Tectonic evolution and structural setting of the Suez Rift. In: London SM (ed) Interior rift basins. American Association of Petroleum Geologists, Memoirs 59:7-55

Salah MG, Alsharhan AS (1997) The Miocene Kareem Formation in the southern Gulf of Suez, Egypt: a review on stratigraphy and petroleum geology. J Pet Geol 20(3):327-346

Walker RG (1978) Deep-water sandstone facies and ancient submarine fans: models for exploration for stratigraphic traps. AAPG Bull 62:932-966

Wescott WA, Krebs WN, Dolson JC, Karamat SA, Nummedal D (1996) Rift basin sequence stratigraphy: some examples from the Gulf of Suez. GeoArabia 1(2):343-358

Xiao M, Yuan X, Cheng D, Wu S, Cao Z, Tang Y, Xie Z (2018) Feldspar dissolution and its influence on reservoirs: a case study of the Lower Triassic Baikouquan Formation in the Northwest Margin of the Junggar Basin, China. Meng. Hindawi Publishing Corporation, Vol. 2018, Issue 2018 (31 Dec. 2018), pp 1-19, 19 p

Zhang L, Luo X, Ye M, Zhang B, Wei H, Cao B, Xu X, Liu Z, Lei Y, Li C (2021) Small-scale diagenetic heterogeneity effects on reservoir quality of deep sandstones: a case study from the Lower Jurassic Ahe Formation, eastern Kuqa Depression. Geofluids 2021:6626652. https://doi.org/10.1155/2021/6626652 